HJIMB Vol 2, No. 1 2020, pp: 76-84

https://doi.org/10.30606/hjimb

\title{
HIRARKI
}

\section{Jurnal Ilmiah Manajemen dan Bisnis} http://iournal.upp.ac.id/index.php/Hirarki

\section{PENGARUH LINGKUNGAN KELUARGA TERHADAP KETERAMPILAN SOSIAL MAHASISWA}

\author{
Welven Aida, Rina Ari Rohmah, Ryan Prayogi
}

Pendidikan IPS, Universitas Pasir Pengaraian

\begin{tabular}{l} 
Info Artikel \\
\hline Sejarah Artikel: \\
Diterima 09 Januari 2020 \\
Disetujui 15 Januari 2020 \\
Dipublikasikan \\
29 Fabruari 2020 \\
\hline Keywords: \\
Kemampuan Sosial, \\
Lingkungan Keluarga, \\
UPP
\end{tabular}

\begin{abstract}
Abstrak
Tujuan dari penelitian ini adalah untuk (1) mengetahui lingkungan keluarga siswa IPS Fakultas Keguruan dan Ilmu Pendidikan, Universitas Pasir Pengaraian, (2) mengetahu keterampilan sosial mahasiswa program studi IPS Fakultas Keguruan dan Pendidikan Gur Universitas Pasir Pengaraian, dan (3) mengetahui pengaruh Lingkungan Keluarga terhadal keterampilan sosial mahasiswa IPS, Fakultas Keguruan dan Ilmu Pendidikan, Universita: Pasir Pengaraian. Variabel yang digunakan dalam penelitian ini adalah Lingkungar Keluarga $(X)$ dan Keterampilan Sosial $(Y)$. Metode yang digunakan untuk menganalisis datc penelitian adalah analisis deskriptif dan analisis regresi sederhana. Teknik pengambilar sampel yang digunakan adalah total sampel dari seluruh populasi. Hasil penelitiar menunjukkan bahwa lingkungan keluarga mahasiswa Program Studi Pendidikan Ilmu Sosia masuk dalam kategori tinggi yang memperoleh skor rata-rata 3,73, sedangkan keterampilar sosial mahasiswa Program Studi Pendidikan Ilmu Sosial termasuk dalam kategori sedan£ sehingga diperoleh skor rata-rata dari 3.13. Sementara itu, pengaruh lingkungan keluargc terhadap keterampilan sosial secara signifikan mempengaruhi persentase 28,9\%. Oleh karenc itu, lingkungan keluarga dapat digunakan sebagai alat prediksi untuk meningkatkar keterampilan sosial siswa.
\end{abstract}

\section{THE EFFECT OF FAMILY ENVIRONMENT ON STUDENTS 'SOCIAL SKILLS}

\begin{abstract}
The purpose of this study was to (1) find out the family environment of social studies students of the Faculty of Teacher Training and Education Sciences, University of Pasir Pengaraian, (2) find out the social skills of students of social studies programs of the Faculty of Teacher Training and Education of the University of Sand Pengaraian, and (3) find out the influence of the Family Environment on the social skills of social studies students of the Faculty of Teacher Training and Education, Pasir Pengaraian University. The variables used in this study are the Family Environment $(X)$ and Social Skills $(Y)$. The method used to analyze research data is descriptive analysis and simple regression analysis. The sampling technique used is the total sample of the entire population. The results showed that the family environment of Social Sciences Education Study Program students entered in the high category that obtained an average score of 3.73, while the social skills of Social Sciences Education Study Program students were included in the moderate category that was obtained an average score of 3.13. Meanwhile, the influence of the family environment on social skills significantly affected the percentage of 28.9\%. Therefore, the family environment can be used as a predictor to improve students' social skills.
\end{abstract}

$\begin{array}{lr}{ }^{凶} \text { Alamat korespondensi : } & \text { ISSN } \\ \text { Universitas Pasir Pengaraian } & 2684-9666 \text { (cetak) } \\ \text { rinaarirohmah@gmail.com } & 2684-8503 \text { (online) }\end{array}$




\section{PENDAHULUAN}

Manusia adalah makhluk sosial (zoon politicon) yang selalu membutuhkan orang lain untuk berinteraksi dan bersosialisasi. Namun, bukanlah hal yang mudah untuk berinteraksi dan bersosialisasi dengan baik, karena pada kenyataannya banyak dijumpai kegagalan dalam menerima informasi dari lawan bicara yang disebabkan oleh keterampilan sosial yang rendah. Oleh karena itu, agar berhasil proses interaksi dan sosialisasi dalam kehidupan sosial dimasyarakat, manusia memerlukan keterampilan sosial. Terkait dengan keterampilan sosial, Rachman (2018:79) menyatakan bahwa keterampilan sosial merupakan kemampuan untuk bersosialisasi dan berinteraksi dengan orang lain dengan cara memahami atau peka terhadap perasaan orang lain tersebut dan mampu menyelesaikan segala perselisihan yang timbul dari interaksi yang telah dilakukan dengan cara yang bertanggung jawab. Keterampilan sosial (sosial skills) merupakan kecakapan yang perlu dimiliki oleh setiap orang termasuk peserta didik karena keterampilan sosial ini merupakan bagian dari kecakapan hidup (life skills). Melalui keterampilan ini jugalah peserta didik akan mampu berinteraksi dan merespon dengan orang lain dengan tepat, bisa berkomunikasi dan berani mengungkapkan perasaan dan pendapat kepada orang lain dengan cara yang baik. Keterampilan sosial dapat diartikan sebagai kemampuan seseorang untuk peka terhadap apa yang dirasakan oleh orang lain serta mampu memahami setiap permasalahan yang dihadapi orang lain dan dapat berinteraksi dengan orang lain dengan cepat sehingga mudah bersosialisasi dengan lingkungan disekelilingnya dengan tetap menjaga perasaan orang lain sehingga kehidupan dalam masyarakat berjalan harmonis.

Keterampilan sosial bukanlah kemampuan yang dibawa individu sejak lahir tetapi diperoleh melalui proses belajar, baik belajar dari orang tua, teman sebaya maupun dari lingkungan masyarakat. Keterampilan sosial ini amat penting dimiliki peserta didik untuk memudahkan anak dalam memenuhi tugas-tugas perkembangannya. Kegagalan anak dalam menguasai keterampilan sosial akan menyebabkan dia sulit menyesuaikan diri dengan lingkungan sekitarnya sehingga akan menyebabkan anak rendah diri, dikucilkan dari pergaulan, cenderung berperilaku anti sosial, bahkan dalam perkembangan yang lebih ekstrim dapat menyebabkan terjadinya gangguan jiwa, kenakalan remaja, tindakan kriminal, tindakan kekerasan, dsb. (Rachman, 2018:85).

Berdasarkan observasi awal penulis pada mahasiswa program studi pendidikan IPS Fakultas Keguruan dan Ilmu Pendidikan Universitas Pasir Pengaraian, teramati bahwa (1) mahasiswa program studi pendidikan IPS Fakultas Keguruan dan Ilmu Pendidikan Universitas Pasir masih kesulitan untuk bekerja sama dengan mahasiswa lainnya, hal ini terlihat jika melaksanakan suatu kegiatan hanya beberapa orang mahasiswa yang mau bekerja dan terlibat dalam kegiatan tersebut; (2) beberapa mahasiswa masih sulit berinteraksi dengan baik serta sulit mengontrol diri. Hal ini terlihat dari pernah terjadinya pertikaian sesama mahasiswa dalam melaksanakan tugas, maupun dalam melakukan sesuatu kegiatan; dan (3) mahasiswa masih kesulitan mengeluarkan pendapat. Hal ini terlihat dalam kegiatan pembelajaran diskusi kelompok di kelas. Adapun faktor-faktor yang mempengaruhi keterampilan sosial menurut Desviyanti dalam Rachman (2018:81) adalah: (1) kondisi anak, hal ini berkaitan dengan temperamen anak, regulasi emosi, serta kemampuan sosial kognitif, dan (2) interaksi anak dengan lingkungannya, hal 
ini berkaitan dengan pola interaksi anak dengan orang tua serta kualitas hubungan pertemanan dan penerimaan anak dalam kelompok merupakan dua faktor eksternal yang cukup berpengaruh bagi perkembangan sosial anak.

Terkait dengan interaksi anak dengan lingkungan, keluarga merupakan lingkungan sosial pertama dan utama bagi anak. Anak memulai proses sosialisasinya dengan orang tua dimulai sejak awal kelahiran. Melalui proses sosialisasi orang tua menjamin bahwa anak mereka memiliki standar perilaku, sikap, keterampilan dan motif-motif yang sedapat mungkin sesuai dengan yang diinginkan atau tepat dengan perannya dalam masyarakat (Hetterington \& Parke dalam Rachman, 2018:83). Oleh karena itu, sebagai figur yang paling dekat dengan anak orang tua sangat berperan dalam mengajarkan keterampilan sosial secara langsung kepada anak.

Berdasarkan wawancara awal penulis dengan beberapa mahasiswa program studi pendidikan IPS Fakultas Keguruan dan Ilmu Pendidikan Universitas Pasir Pengaraian, terungkap bahwa permasalahan yang berkaitan dengan lingkungan keluarga mahasiswa meliputi: (1) sebagian orang tua mahasiswa masih membatasi dan melarang mahasiswa dalam melakukan kegiatan diluar kampus seperti contohnya pergi studi banding keluar kota; (2) interaksi dan komunikasi dengan orang tua kadang tidak berjalan dengan baik; dan (3) sebagian orang tua mahasiswa tidak memberikan tugas dan tanggung jawab yang sesuai dengan perkembangan kepada mahasiswa, misalnya menyelesaikan pembayaran SPP sendiri serta mengatur keuangan mahasiswa sendiri.

Mariyana, dkk (2010:16) menjelaskan bahwa lingkungan merupakan suatu tempat atau suasana yang dapat mempengaruhi pertumbuhan dan perkembangan seseorang. Selanjutnya menurut Shochib (2000:17), ditinjau dari dimensi hubungan darah, lingkungan keluarga merupakan suatu kesatuan sosial yang diikat oleh hubungan darah antara satu dengan yang lainnya. Berdasarkan dimensi hubungan darah ini, keluarga dapat dibedakan menjadi keluarga besar dan keluarga inti.

Lingkungan keluarga memiliki pengaruh yang cukup besar terhadap keterampilan sosial anak. Hal ini sesuai dengan pendapat Hetherington \& Parke dalam Rachman (2018:83) bahwa keterampilan sosial anak terutama dipengaruhi oleh proses sosialisasinya dengan orang tua yang mulai terjalin sejak awal kelahiran. Melalui proses sosialisasi ini, orang tua menjamin bahwa anak mereka memiliki standar perilaku, sikap, keterampilan, dan motif-motif yang sedapat mungkin sesuai yang diinginkan dengan perannya dalam masyarakat.

Merujuk pada hasil penelitian Lestiawati (2013:111) bahwa terdapat pengaruh yang positif dan signifikan antara pola asuh orang tua terhadap kemampuan sosial anak, yaitu kemampuuan sosial anak dengan pola asuh orang tua demokratis lebih tinggi dibandingkan dengan kemampuan sosial anak dengan pola asuh otoriter. Implikasi dari penelitian ini yaitu pola asuh orang tua demokratis dapat mengembangkan kemampuan sosial anak yang tinggi sebagai sarana interaksi anak dengan lingkungan. Terkait dengan pengaruh pola asuh orang tua terhadap kemampuan sosial, hal ini relevan dengan yang dibahas dalam penelitian ini karena pola asuh orang tua termasuk dalam indikator lingkungan keluarga dan kemampuan sosial sama halnya dengan keterampilan sosial.

Selanjutnya, hasil penelitian Seftannency (2015:1) menunjukkan bahwa lingkungan keluarga memberikan pengaruh terhadap hasil belajar siswa pada mata pelajaran ekonomi sebesar 41,9\%. Artinya, hasil 
belajar siswa dapat meningkat apabila mempunyai lingkungan keluarga yang baik. Terkait dengan hasil belajar, keterampilan sosial merupakan cakupan dari hasil belajar. Jadi, lingkungan keluarga juga membawa pengaruh terhadap keterampilan sosial mahasiswa.

Berdasarkan uraian di atas, dapat disimpulkan bahwa lingkungan keluarga diasumsikan dapat memberikan pengaruh terhadap keterampilan sosial mahasiswa. Oleh sebab itu, penelitian ini penting dilakukan untuk mengungkapkan seberapa besar pengaruh lingkungan keluarga terhadap keterampilan sosial mahasiswa program studi Pendidikan IPS Fakultas Keguruan dan Ilmu Pendidikan Universitas Pasir Pengaraian.

\section{METODE PENELITIAN}

Penelitian ini menggunakan pendekatan kuantitatif dengan teknik analisis regresi. Variabel bebas dalam penelitian ini yaitu lingkungan keluarga (X) sedangkan variabel terikatnya adalah keterampilan sosial (Y). Pengaruh lingkungan keluarga terhadap keterampilan sosial dapat dibuktikan secara statistik melalui pengambilan data secara empiris. Sampel diambil dengan teknik total sampling yaitu sebanyak 87 mahasiswa prodi Pendidikan IPS.

Data penelitian lingkungan keluarga dan keterampilan sosial diperoleh melalui hasil penyebaran angket. Angket lingkungan keluarga mencakup indikator memberi anak kesempatan untuk berhubungan dengan teman sebaya; mengawasi pertemuan anak dengan teman sebayanya; mengajarkan anak untuk mampu memenuhi tugas-tugas yang berkaitan dengan hubungan interpersonal dengan teman sebaya; dan menegakkan disiplin terhadap perilaku yang tidak dapat diterima. Sementara itu, angket keterampilan sosial mencakup indikator perilaku interpersonal; perilaku yang berhubungan dengan diri sendiri; perilaku yang berhubungan dengan kesuksesan akademis; perilaku yang berhubungan dengan penerimaan sebaya; dan keterampilan komunikasi.

Angket untuk penelitian ini berjumlah 15 item dan disusun menurut pola skala Likert dengan lima alternatif pilihan yaitu selalu $(S L)=5$, sering $(S R)=4$, Kadang-kadang $(\mathrm{KD})=3$, jarang $(\mathrm{JR})=2$, dan tidak pernah $(\mathrm{TP})=1$. Sedangkan skor untuk setiap pernyataan negatif adalah sebaliknya. Teknik analisis data meliputi analisis deskriptif dan analisis regresi sederhana. Pengolahan dan analisis data menggunakan bantuan software IBM SPSS Statistics 25

\section{HASIL DAN PEMBAHASAN \\ 1. Analisis Deskriptif Variabel Lingkungan Keluarga}

Berdasarkan hasil penelitian, informasi deskriptif variabel lingkungan keluarga dapat digambarkan pada tabel 1 . di bawah ini.

Tabel 1. Tanggapan tentang Lingkungan Keluarga

\begin{tabular}{|c|l|c|}
\hline No & \multicolumn{1}{|c|}{ Pernyataan } & $\begin{array}{c}\text { Kriteria } \\
\text { Lingkungan } \\
\text { Keluarga }\end{array}$ \\
\hline 1 & $\begin{array}{l}\text { Orang tua memberikan } \\
\text { dukungan kepada saya } \\
\text { untuk belajar bersama } \\
\text { teman-teman sekelas. }\end{array}$ & $\begin{array}{c}\text { Sangat } \\
\text { Tinggi }\end{array}$ \\
\hline 2 & $\begin{array}{l}\text { Orang tua menyarankan } \\
\text { saya untuk bergaul } \\
\text { dengan teman sebaya di } \\
\text { lingkungan kampus }\end{array}$ & Tinggi \\
\hline 3 & $\begin{array}{l}\text { Orang tua melarang saya } \\
\text { untuk bergaul dengan } \\
\text { teman sebaya di } \\
\text { lingkungan tempat } \\
\text { tinggal }\end{array}$ & $\begin{array}{c}\text { Sangat } \\
\text { Rendah }\end{array}$ \\
\hline
\end{tabular}




\begin{tabular}{|c|c|c|}
\hline No & Pernyataan & $\begin{array}{c}\text { Kriteria } \\
\text { Lingkungan } \\
\text { Keluarga }\end{array}$ \\
\hline 4 & $\begin{array}{l}\text { Orang tua menasihati } \\
\text { saya untuk bergaul } \\
\text { dengan teman yang baik }\end{array}$ & $\begin{array}{l}\text { Sangat } \\
\text { Tinggi }\end{array}$ \\
\hline 5 & $\begin{array}{l}\text { Orangtua mengajak saya } \\
\text { berdiskusi tentang } \\
\text { teman-teman saya }\end{array}$ & Sedang \\
\hline 6 & $\begin{array}{l}\text { Saya mematuhi } \\
\text { peraturan orang tua } \\
\text { untuk membagi waktu } \\
\text { antara bermain dan } \\
\text { belajar }\end{array}$ & Tinggi \\
\hline 7 & $\begin{array}{l}\text { Orang tua kenal dengan } \\
\text { semua teman-teman saya }\end{array}$ & Tinggi \\
\hline 8 & $\begin{array}{l}\text { Orang tua membebaskan } \\
\text { saya untuk pergi ketika } \\
\text { ada tugas kelompok di } \\
\text { rumah teman yang jauh }\end{array}$ & Tinggi \\
\hline 9 & $\begin{array}{l}\text { Saya dan teman saling } \\
\text { membantu saat menemui } \\
\text { kesulitan. }\end{array}$ & $\begin{array}{l}\text { Sangat } \\
\text { Tinggi }\end{array}$ \\
\hline 10 & $\begin{array}{l}\text { Orang tua mengajak saya } \\
\text { berkenalan dengan } \\
\text { teman baru yang sebaya }\end{array}$ & Sedang \\
\hline 11 & $\begin{array}{l}\text { Saya dan teman saling } \\
\text { memotivasi untuk giat } \\
\text { belajar dan memperoleh } \\
\text { nilai yang memuaskan }\end{array}$ & $\begin{array}{l}\text { Sangat } \\
\text { Tinggi }\end{array}$ \\
\hline 12 & $\begin{array}{l}\text { Saat diskusi berlangsung } \\
\text { saya hanya } \\
\text { mengandalkan teman } \\
\text { saya }\end{array}$ & Rendah \\
\hline 13 & $\begin{array}{l}\text { Orang tua mendidik saya } \\
\text { untuk mematuhi } \\
\text { peraturan di rumah } \\
\text { maupun di kampus }\end{array}$ & $\begin{array}{l}\text { Sangat } \\
\text { Tinggi }\end{array}$ \\
\hline 14 & $\begin{array}{l}\text { Saya mengikuti mata } \\
\text { kuliah dari awal hingga } \\
\text { akhir waktu yang } \\
\text { ditentukan }\end{array}$ & $\begin{array}{l}\text { Sangat } \\
\text { Tinggi }\end{array}$ \\
\hline 15 & $\begin{array}{l}\text { Orangtua akan menegur } \\
\text { saya saat saya terlambat } \\
\text { berangkat ke kampus }\end{array}$ & $\begin{array}{l}\text { Sangat } \\
\text { Tinggi }\end{array}$ \\
\hline
\end{tabular}

Berdasarkan tabel di atas, secara umum lingkungan keluarga mahasiswa IPS masuk pada kategori tinggi yaitu diperoleh skor rata-rata 3,73. Penilaian persepsi lingkungan keluarga tertinggi terdapat pada aspek mengikuti mata kuliah dari awal hingga akhir waktu yang ditentukan (skor 4,82). Selanjutnya berturut-turut yang masuk pada kategori sangat tinggi adalah pada aspek: peran orang tua yang mendidik anak untuk mematuhi peraturan di rumah maupun kampus (skor 4,79); menasihati agar bergaul dengan teman yang baik (skor 4,57); orang tua menegur ketika anak terlambat berangkat kampus (skor 4,38); orang tua memberikan dukungan untuk belajar bersama teman-teman sekelas (skor 4,37); saling membantu saat menemui kesulitan (skor 4,23); dan saling memotivasi untuk giat belajar agar memperoleh nilai yang memuaskan (skor 4,23).

Sementara itu, aspek lingkungan keluarga yang masuk pada kategori tinggi terdiri atas aspek: mematuhi peraturan orang tua untuk membagi waktu antara bermain dan belajar (skor 4,18); orang tua menyarakan agar bergaul dengan teman sebaya di lingungan kampus (skor 3,98); orang tua kenal dengan semua temanteman (skor 3,63); orang tua membebaskan untuk mengkuti tugas kelompok di rumah teman yang jauh (skor 3,44).

Selanjutnya, aspek lingkungan keluarga yang tergolong pada kategori sedang terdapat pada aspek: orang tua mengajak berdiskusi tentang temanteman (skor 3,29) dan orang tua mengajak berkenalan dengan teman baru yang sebaya (skor 2,60). Terakhir aspek lingkungan keluarga yang tergolong rendah dan sangat rendah terdapat pada aspek: mahasiswa yang hanya mengandalkan teman (skor 1,82) dan orang tua melarang bergaul dengan teman sebaya (skor 1,70).

Berdasarkan

tanggapan mahasiswa terhadap aspek lingkungan keluarga, terungkap bahwa perolehan 
nilai tertinggi terdapat pada indikator menegakkan disiplin terhadap perilaku yang tidak dapat diterima dan maladaptif, yaitu pada pernyataan "Saya mengikuti mata kuliah dari awal hingga akhir waktu yang ditentukan". Hal ini menunjukkan bahwa peran orang tua sudah baik karena telah menerapkan disiplin kepada anaknya untuk mengikuti proses pembelajaran yang ada di kampus. Hal ini terlihat pada daftar hadir mahasiswa yang selalu konsisten mengikuti pelajaran dari awal higga akhir pembelajaran. Pada indikator ini, terdapat juga peran orang tua yang baik dalam mendidik anak untuk disiplin yaitu dengan cara menegur apabila anak terlambat berangkat ke kampus dan senantiasa mematuhi peraturan yang ada di rumah maupun di kampus.

Terkait dengan peran orang tua dalam mendidik anak, hasil penelitian Suharsono (2009: 3) menunjukkan bahwa terdapat korelasi antara pola asuh orang tua dengan kemampuan sosialisasi anak usia prasekolah menunjukkan terdapat hubungan yang sangat signifikan $(\mathrm{p}=$ $0,00)$. Hasil penelitian ini juga didukung oleh penelitian dari Cristiany (2014) yang menyatakan bahwa, terdapat hubungan positif dan signifikan antara pola asuh orangtua demokratis dengan kompetensi siswa. Ini menunjukkan apabila pola asuh orangtua demokratis tinggi, maka akan meningkatkan kompetensi sosial siswa. Terkait dengan pola asuh, lingkungan keluarga merupakan bagian di dalamnya dan kompetensi sosial merupakan bagian dari keterampilan sosial. Jadi, lingkungan keluarga memberikan pengaruh terhadap keterampilan sosial.

Berdasarkan uraian di atas, jelas bahwa lingkungan keluarga yang di dalamnya meliputi aspek pola asuh yang baik akan menghasilkan keterampilan sosial yang baik pula. Karakteristik lingkungan keluarga yang baik meliputi orang tua yang selalu mendukung dalam hal kebaikan dan masa depan, memberikan kesempatan untuk bergaul dengan teman sebaya, mengawasi pertemuan anak dengan teman sebaya, mengajarkan anak untuk mampu memenuhi tugas-tugas yang berkenaan dengan hubungan interpersonal, dan menegakkan disiplin terhadap perilaku yang tidak dapat diterima.

\section{Analisis Deskriptif Variabel Keterampilan Sosial}

Informasi deskriptif terkait variabel keterampilan sosial mahasiswa dapat digambarkan pada tabel 2 berikut ini.

Tabel 2. Deskripsi Keterampilan Sosial

\begin{tabular}{|c|c|c|}
\hline No & Pernyataan & $\begin{array}{c}\text { Kriteria } \\
\text { Lingkungan } \\
\text { Sosial }\end{array}$ \\
\hline 1 & $\begin{array}{l}\text { Saya } \\
\text { mendengarkan } \\
\text { teman saya saat } \\
\text { mereka } \\
\text { menceritakan } \\
\text { masalah yang } \\
\text { dihadapinya kepada } \\
\text { saya. } \\
\end{array}$ & $\begin{array}{l}\text { Sangat } \\
\text { Tinggi }\end{array}$ \\
\hline 2 & $\begin{array}{l}\text { Saya memulai } \\
\text { percakapan dengan } \\
\text { teman lawan jenis } \\
\text { dengan mudah } \\
\text { tanpa ragu }\end{array}$ & Sedang \\
\hline 3 & $\begin{array}{l}\text { Saya berjalan agak } \\
\text { membungkuk } \\
\text { ketika lewat di } \\
\text { depan orang yang } \\
\text { lebih tua }\end{array}$ & $\begin{array}{l}\text { Sangat } \\
\text { Tinggi }\end{array}$ \\
\hline 4 & $\begin{array}{lr}\text { Saya } & \text { sulit } \\
\text { menerima } & \text { akibat } \\
\text { kesalahan } & \text { yang } \\
\text { saya } & \text { perbuat } \\
\text { sendiri } & \end{array}$ & Sedang \\
\hline 5 & $\begin{array}{l}\text { Saya bernyanyi di } \\
\text { depan kelas karena } \\
\text { tidak mengerjakan } \\
\text { tugas }\end{array}$ & $\begin{array}{l}\text { Sangat } \\
\text { Rendah }\end{array}$ \\
\hline 6 & $\begin{array}{lr}\text { Saya mengikuti } \\
\text { remidial } & \text { ketika } \\
\text { nilai saya jelek }\end{array}$ & Tinggi \\
\hline 7 & bertanya & Rendah \\
\hline
\end{tabular}




\begin{tabular}{|c|c|c|}
\hline No & $\begin{array}{l}\text { Pernyataan } \\
\text { kepada teman saat } \\
\text { ujian }\end{array}$ & $\begin{array}{c}\text { Kriteria } \\
\text { Lingkungan } \\
\text { Sosial }\end{array}$ \\
\hline 8 & $\begin{array}{lr}\text { Saya } & \text { bertanya } \\
\text { kepada dosen } & \text { ketika tidak dapat } \\
\text { mengerjakan tugas }\end{array}$ & Tinggi \\
\hline 9 & $\begin{array}{l}\text { Saya malu bertanya } \\
\text { jika tidak mengerti } \\
\text { penjelasan dosen }\end{array}$ & Sedang \\
\hline 10 & $\begin{array}{lr}\text { Saya } & \text { menjadi } \\
\text { ketua dalam } \\
\text { kegiatan-kegiatan } \\
\text { di kampus }\end{array}$ & Rendah \\
\hline 11 & $\begin{array}{l}\text { Saya gengsi ketika } \\
\text { harus meminta } \\
\text { maaf kepada teman }\end{array}$ & Rendah \\
\hline 12 & $\begin{array}{lr}\text { Saya bersemangat } \\
\text { saat } & \text { teman } \\
\text { mengajak } & \text { saya } \\
\text { bercerita } & \end{array}$ & Tinggi \\
\hline 13 & $\begin{array}{lr}\text { Saya } & \text { menanyakan } \\
\text { kabar } & \text { teman yang } \\
\text { tidak } & \text { masuk } \\
\text { kampus } & \\
\end{array}$ & Tinggi \\
\hline 14 & $\begin{array}{lr}\text { Saya } & \text { banyak } \\
\text { berbicara } & \text { ketika } \\
\text { berkumpul dengan } & \text { deman-teman }\end{array}$ & Tinggi \\
\hline 15 & $\begin{array}{l}\text { Saya } \\
\text { menyampaikan } \\
\text { presentasi yang } \\
\text { menarik untuk } \\
\text { menarik perhatian } \\
\text { orang lain }\end{array}$ & Sedang \\
\hline
\end{tabular}

Berdasarkan tabel tersebut tampak bahwa secara umum keterampilan sosial mahasiswa Prodi Pendidikan IPS FKIP UPP masuk dalam kategori sedang yaitu diperoleh skor rata-rata 3,13. Penilaian persepsi keterampilan sosial tertinggi terdapat pada aspek saya berjalan agak membungkuk ketika melewati orang yang lebih tua (skor 4,82) dan mendengarkan masalah yang dihadapi teman (skor 4,40). Selanjutnya berturut-turut yang masuk pada kategori tinggi adalah pada aspek: menanyakan kabar teman yang tidak masuk kampus (skor 3,94); bersemangat mendengarkan cerita teman (skor 3,86); banyak berbicara ketika berkumpul dengan teman-teman (skor 3,79); mengikuti remidial ketika mendapatkan nilai jelek (skor 4,64); bertanya kepada dosen ketika tidak dapat mengerjakan tugas (skor 3,43).

Sementara itu, aspek keterampilan sosial yang masuk pada kategori sedang terdiri atas aspek: sulit menerima kesalahan diri sendiri (skor 2,84); tidak ragu memulai percakapan dengan lawan jenis (skor 2,78); malu bertanya pada dosen (skor 2,71); menyampaikan presentasi yang menarik (skor 3,25).

Selanjutnya, aspek keterampilan sosial yang tergolong pada kategori rendah terdapat pada aspek: bertanya kepada teman saat ujian (skor 2,43); menjadi ketua dalam kegiatan di kampus (skor 2,09); dan gengsi ketika harus meminta maaf kepada teman (skor1,80). Terakhir, aspek keterampilan sosial yang tergolong sangat rendah terdapat pada aspek: bernyanyi di depan kelas karena tidak mengerjakan tugas (skor 1,41).

Berdasarkan tanggapan mahasiswa terhadap aspek keterampilan sosial, terungkap bahwa perolehan nilai tertinggi terdapat pada indikator perilaku yang berhubungan dengan diri sendiri, yaitu pada pernyataan "Saya berjalan agak membungkuk ketika lewat di depan orang yang lebih tua". Hal ini menunjukkan bahwa mahasiswa mampu menempatkan dirinya pada posisi yang tinggi. Seseorang yang mempunyai keterampilan yang bagus adalah seseorang yang menjujung moral dan etika. Pada indikator ini, terdapat juga mahasiswa yang mengikuti remidial ketika mendapatkan nilai yang jelek. Berarti dalam hal ini mahasiswa tersebut peduli terhadap dirinya sendiri dengan cara memperbaiki nilai yang diperoleh demi masa depan. 
Terkait dengan keterampilan sosial, hasil penelitian Jati (2018) mengungkapkan bahwa cakupan keterampilan sosial meliputi: berani bertanya kepada guru ketika ada mata pelajaran yang tidak dimengerti, berani menyampaikan pendapat tanpa melukai hati orang lain, mulai menyukai belajar kelompok, dan mulai berani untuk mengerjakan soal di depan kelas. Ciri-ciri pribadi seseorang yang memiliki sikap percaya diri dalam hal keterampilan sosial meliputi bisa menghargai usahanya sendiri dan berani menyampaikan pendapat.

Sementara itu, hasil penelitian Napis (2019:98) mengungkapkan bahwa mahasiswa yang memiliki keterampilan sosial yang baik akan memudahkan dalam berinteraksi, berkomunikasi, dan bertanya dalam upaya mencari jawaban atau solusi pemecahan masalah. Selanjutnya, hasil penelitian Mayasari (2014) menjelaskan bahwa hubungan sosial yang baik menjadi salah satu unsur penting dalam pembentukan kesejahteraan psikologis. Seseorang baru dapat membangun hubungan sosial yang positif dan memerlukan kemampuan atau keterampilan sosial. Keterampilan sosial ini berhubungan dengan kemampuan mengawali dan mempertahankan hubungan dengan cara yang efektif. Selain itu, individu tidak cukup hanya memiliki keterampilan sosial tetapi juga harus yakin dapat memanfaatkannya dalam situasi sosial. Kedua hal ini diperoleh dari hasil belajar seseorang dengan lingkungannya.

Berdasarkan uraian di atas,dapat disimpulkan bahwa keterampilan sosial itu penting dimiliki setiap manusia, terlebih mahasiswa. Mahasiswa yang memiliki keterampilan sosial yang baik akan memudahkan dalam berinteraksi, berkomunikasi, dan bertanya dalam upaya mencari jawaban atau solusi pemecahan masalah. Cakupan dari keterampilan sosial itu sendiri meliputi perilaku interpersonal, perilaku yang berhubungan dengan diri sendiri, perilaku yang berhubungan dengan kesuksesan akademis, perilaku yang berhubungan dengan penerimaan sebaya, dan keterampilan komunikasi.

\section{Analisis Deskriptif Pengaruh Lingkungan Keluarga terhadap Keterampilan Sosial}

Hipotesis yang diuji dalam penelitian ini adalah lingkungan keluarga berpengaruh positif terhadap keterampilan sosial. Hipotesis penelitian ini menjelaskan bahwa semakin kondusif lingkungan keluarga maka akan meningkatkan keterampilan sosial mahasiswa. Untuk menguji hipotesis penelitian ini, digunakan persamaan regresi linear sederhana. Selanjutnya, untuk mengetahui hubungan secara parsial antara variabel lingkungan keluarga dengan keterampilan sosial dapat dilihat pada tabel berikut.

Tabel 3 Uji Coefficients Regresi $\widehat{\boldsymbol{Y}}=41,746+0,298 \boldsymbol{X}$

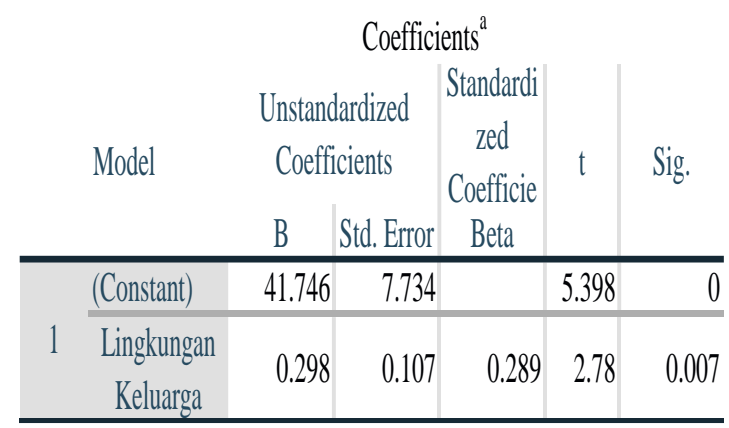

Berdasarkan hasil analisis regresi linear sederhana antara pasangan data lingkungan keluarga dengan keterampilan sosial maka diperooleh nilai koefisien regresi (b) sebesar 0.298 dan nilai konstanta (a) sebesar 41.746. Dengan demikian maka bentuk hubungan antara variabel lingkungan keluarga dan keterampilan sosial dapat juga ditunjukan 
dengan persamaan regresi linear sederhana Regresi $\widehat{\boldsymbol{Y}}=41,746+0,298 \boldsymbol{X}$. Persamaan regresi ini menunjukan bahwa setiap kenaikan atau penurunan satu unit skor variabel lingkungan keluarga, maka akan diikuti oleh kenaikan atau penurunan skor variabel keterampilan sosial 0.298 pada konstanta 41.746.

Tabel 4. Uji Summary Model Summary

\begin{tabular}{ll|l|l|} 
Model & R & R Square & Adjusted \\
R Square
\end{tabular}

\section{1}

$.289^{\mathrm{a}}$
0.083
0.073
Berdasarkan tabel di atas tampak

bahwa besarnya hubungan antara lingkungan keluarga dengan keterampilan sosial dihitung dengan koefisien korelasi adalah 0,289 (Rx1y = 0,289 ). Sedangkan kontribusi variabel lingkungan keluarga terhadap keterampilan sosial adalah $=\mathrm{R}^{2}=0.289$, ini berarti bahwa $28,9 \%$ keterampilan sosial dipengaruhi oleh variabel lingkungan keluarga sedangkan sisanya dipengaruhi oleh variabel lain yang tidak diteliti pada penelitian ini.

Simpulan dari uraian di atas adalah lingkungan keluarga berpengaruh positif dan signifikan terhadap keterampilan sosial mahasiswa. Lingkungan keluarga dapat dijadikan prediktor untuk meningkatkan keterampilan sosial mahasiswa. Semakin baik dan kondusif lingkungan keluarga maka semakin meningkatkan keterampilan sosial mahasiswa, begitu pula sebaliknya. Hal ini sejalan dengan penelitian yang dilakukan oleh penelitian Blazevic (2016) bahwa keluarga berpengaruh terhadap perkembangan sosial siswa. Hal tersebut penting untuk menciptakan kegiatan sosial yang akan mendorong pembangunan sosial dan juga integral siswa.
Selanjutnya, hasil penelitian Guiqing An (2019:41) mengungkapkan bahwa orang tua berpartisipasi dalam pendidikan anak, partisipasi emosional memiliki dampak terbesar pada prestasi akademik anak dan dapat mengimbangi efek negatif yang ditimbulkan oleh beberapa faktor keluarga yang merugikan. Penelitiannya tersebut dilakukan untuk mengeksplorasi pengaruh lingkungan keluarga dan stasnitif orang tua, emosi, dan partisipasi perilaku dalam pendidikan sekolah anak. Jadi, jelas bahwa lingkungan keluarga Estimate haPinP keterampilan sosial juga termasuk dalam pendidikan anak.

\section{KESIMPULAN}

Lingkungan keluarga dapat dijadikan prediktor untuk meningkatkan keterampilan sosial mahasiswa. Semakin baik lingkungan keluarga semakin baik pula keterampilan sosial yang dimiliki mahasiswa. Oleh sebab itu, untuk meningkatkan keterampilan sosial mahasiswa, orang tua atau pun orang yang terdekat dengan mahasiswa selalu mendukung kegiatan mahasiswa, mengawasi pertemanan mahasiswa, mengajarkan untuk mampu memenuhi tugas-tugas yang berkaitan dengan interpersonal dengan teman sebayanya, dan menegakkan disiplin terhadap perilaku yang tidak dapat diterima dan maladaptif. Adapun saran yang dapat diberikan berdasarkan hasil penelitian adalah sebagai berikut. Pertama, orang tua hendaknya selalu menciptakan lingkungan keluarga yang kondusif, harmonis, dan sesuai dengan nilai-nilai yang berlaku di masyarakat agar mahasiswa memiliki keterampilan sosial yang baik. Kedua, bagi peneliti yang tertarik dengan keterampilan sosial, dapat mengkaji faktor-faktor lain yang 
kemungkinan memberikan pengaruh terhadap variabel tersebut

\section{DAFTAR PUSTAKA}

Blazevic, Ines. 2016. "Family, Peer and School Influence on Children's Social Development". World Journal of Education, Vol. 6, No. 2.

Cristiany. 2014. "Konsep Diri, Pola Asuh Orang Tua Demokratis dan Kompetensi Sosial Siswa". Jurnal Psikologi Indonesia, Vol. 3, No. 1. Hlmn 9-21.

Jati, Ririh Pintoko, dkk. 2018. "Analisis Keterampilan Sosial Siswa pada Pembelajaran IPS di SMP N 3 Pardasuka". Jurnal Studi Sosial, Vol. 6. No. 1.

Lestiawati, I Made. 2013. "Pengaruh Pola Asuh Orang Tua terhadap Kemampuan Sosial Anak Usia 6-7 Tahun". Jurnal Ilmiah VISI P2TK PAUDNI, Vol. 8, No.2, HImn. 111-119.

Mariyana, Rita. 2010. Pengelolaan Lingkungan Belajar. Jakarta: Kencana.

Mayasari. 2014. "Pengaruh Keterampilan Sosial dan Efikasi Diri Sosial terhadap kesejahteraan Psikologis". Jurnal Al-Munzir, Vol. 7, No. 1.

Napis dan Rahmatulloh. 2019. "Pengaruh Keterampilan Sosial terhadap Pemecahan Masalah dalam Pembelajaran Fisika". Prosiding Seminar Nasional Pendidikan Kaluni, Vo. 2, hlm. 98.
Petrict, Bojana. 2002. "Students Attitudes towards Writing and Development of Academic Writing Skills". Writing Center Journal, Vol. 22, No.2, p9-27.

Guiqing An. 2019. "Study on the Effects to Students' STEM Academic Achievement with Chinese Parents' Participative Styles in School Education". Educational Sciences: Theory \& Practice, eISSN: 2148-7561, ISSN: 26305984, p41-54.

Rachman, Huriah.2018. Berfikir sosial \&keterampilan sosial. Bandung: Alfabeta.

Seftannency. 2015. "Pengaruh Lingkungan Keluarga terhadap Hasil Belajar Siswa pada Pelajaran Ekonomi di SMAK Abdi Wacana". Jurnal Pendidikan dan Pembelajaran Khatulistiwa, Vol. 4, No. 9.

Shochib, M. 2000. Pola Asuh Orang Tua dalam Membantu Anak Mengembangkan Disiplin Diri. Jakarta: Rineka Cipta.

Suharsono, T. J. 2009.. "Hubungan Pola Asuh Orang Tua terhadap Kemampuan Sosialisasi pada Anak Prasekolah di TK Pertiwi Purwekerto Utara". Jurnal Keperawatan Soederman, 4 (3), 112-116. 